\title{
Four months of rifampicin monotherapy for latent tuberculosis infection in children
}

\author{
Chi Eun Oh, MD ${ }^{1}$, Dick Menzies, $\mathrm{MD}^{2}$ \\ ${ }^{1}$ Department of Pediatrics, Kosin University College of Medicine, Busan, Korea; ${ }^{2}$ Respiratory Epidemiology and Clinical Research Unit, McGill International TB Centre, \\ McGill University, Montreal, QC, Canada
}

Diagnosing and treating latent tuberculosis infection (LTBI) is an important part of efforts to combat tuberculosis (TB). The Korean guidelines for TB published in 2020 recommend 2 LTBI regimens for children and adolescents: 9 months of daily isoniazid $(9 \mathrm{H})$ and 3 months of daily isoniazid plus rifampicin. Isoniazid for 6-12 months has been used to effectively treat LTBI in children for over 50 years. However, a long treatment period results in poor patient compliance. This review summarizes pediatric data on the treatment completion rate, safety, and efficacy of 4 months of daily rifampicin (4R) and evaluates the pharmacokinetics and pharmacodynamics of rifampicin in children. The $4 \mathrm{R}$ regimen has a higher treatment completion rate than the $9 \mathrm{H}$ regimen and equivalent safety in children. The efficacy of preventing TB is also consistent with that of $9 \mathrm{H}$ when summarizing reports published to date. A shorter treatment period could increase patient compliance and, therefore, prevent TB in more patients. By using an effective, safe, and highly compliant regimen for the treatment of children with LTBI, we would become one step closer to our goal of eradicating TB.

Key words: Child, Latent tuberculosis, Patient compliance, Rifampicin

\section{Key message}

- Recently, the importance of a short-term treatment regimen including rifamycin has been highlighted in the treatment of latent tuberculosis infection (LTBI).

- Four prospective or retrospective studies in children consistently reported that a 4-month daily rifampicin regimen (4R) had a higher completion rate than and comparable safety to a nine-month daily isoniazid regimen.

- We suggest rifampicin $20-30 \mathrm{mg} / \mathrm{kg} /$ day for children aged 0-2 years and $15-20 \mathrm{mg} / \mathrm{kg} /$ day for children aged 2-10 years in 4R to treat LTBI.

\section{Introduction}

Diagnosing and treating latent tuberculosis infection (LTBI) is an important part of the effort to combat tuberculosis (TB). Worldwide, an estimated 1.7 billion people, or about a quarter of the population, are infected with Mycobacterium tuberculosis. ${ }^{1)}$ The prevalence of TB infection estimated by the tuberculin skin test (TST) in boys (girls) aged 10-14 years in Korea was 74.5\% $(67.9 \%)$ in 1965 and decreased to $16.5 \%$ (16.9\%) by 1995.2) In 2016, when the prevalence of LTBI among Korean citizens aged 10-64 years was investigated, the TST-positive rate of all subjects was $33.2 \%$, while that of the population aged 10-19 years was $6.5 \%{ }^{3}{ }^{3}$ The management of LTBI in Korea is gradually expanding and comprises an essential element of the national $\mathrm{TB}$ control plan. ${ }^{4,5)}$ In 2004, LTBI examinations were conducted for family contacts aged $<6$ years. In 2008 , the contact screening age was expanded to $<18$ years. Since 2013, contact screenings have included families as well as daycare centers, kindergartens, and schools to identify and treat infected children and adolescents. ${ }^{4,6)}$ Since 2015, the Korean government has covered the cost of treatment for all citizens with LTBI. ${ }^{\text {) }}$

The 4th edition of the Korean Guidelines for Tuberculosis published in 2020 recommends 2 regimens for treating LTBI in children and adolescents: 9 months of daily isoniazid $(9 \mathrm{H})$ and 3 months of daily isoniazid plus rifampicin (3HR). ${ }^{7)}$ Traditionally, rifampicin monotherapy was primarily used only when isoniazid was not available. ${ }^{8)}$ However, in recent years, rifamycin-based regimens, which feature a shorter treatment duration than $9 \mathrm{H}$, are recommended to increase the treatment completion rate. In 2020, the Centers for Disease Control and Prevention (CDC) recommended 3 months of once-weekly isoniazid plus rifapentine (3HP) for children aged $>2$ years and 4 months of daily rifampicin (4R) for children of all ages. A regimen of 3 months of daily isoniazid plus rifampicin was conditionally recommended for children of all ages.") Among these drugs, rifapentine is currently not available in Korea.

LTBI treatment in children began in 1954 by Dr. Lincoln. ${ }^{10)}$ She found that isoniazid administration prevented meningeal

\footnotetext{
Corresponding author: Dick Menzies, MD. Respiratory Epidemiology and Clinical Research Unit, McGill International TB Centre, McGill University, Office 3D.58, 5252 Boulevard de Maisonneuve O, Montr al, QB H4A 3S5, Canada

凶Email: dick.menzies@mcgill.ca, https://orcid.org/0000-0003-1601-4514

Received: 11 August, 2021, Revised: 5 October, 2021, Accepted: 14 October, 2021

This is an open-access article distributed under the terms of the Creative Commons Attribution Non-Commercial License (http://creativecommons.org/licenses/bync/4.0/) which permits unrestricted non-commercial use, distribution, and reproduction in any medium, provided the original work is properly cited.

Copyright (c) 2022 by The Korean Pediatric Society
} 
TB in children with asymptomatic primary TB. The first placebo-controlled study of rifampicin monotherapy was conducted in Hong Kong in patients with silicosis. This study compared 4 groups: daily isoniazid for 6 months, 3HR, 3 months of daily rifampicin (3R), and placebo. The results showed no difference between the 3 treatment regimens for $\mathrm{TB}$ disease prevention, although the incidence of TB disease and hepatotoxicity was lowest in the group receiving $3 R .{ }^{11)}$ The American Thoracic Society recommended 4R as an alternative regimen in 2000. Subsequent randomized trials in adults consistently demonstrated better treatment completion rates, with significantly fewer adverse events, particularly grade $3-4$ liver toxicity, than $9 \mathrm{H}^{8,9,12)}$

This review summarizes pediatric data on the treatment completion rate, safety, and efficacy of $4 \mathrm{R}$ and evaluates the pharmacokinetics and pharmacodynamics of rifampicin in children and the recent safety issues associated with rifampicin.

\section{Characteristics of rifampicin for treating TB in children}

\section{Antibacterial activity}

Rifampicin was developed in 1965 by Dow-Lepetit Research Laboratories (Milan, Italy). ${ }^{13)}$ It is a semisynthetic derivative of rifamycin $b$, which inhibits bacterial RNA synthesis by binding to the beta subunit of DNA-dependent RNA polymerase, interfering with RNA transcription, and eventually inhibiting protein synthesis. ${ }^{14)}$ Rifampicin exerts antibacterial activity against gram-positive and -negative bacteria, intracellular pathogens (including Chlamydia, Legionella, Brucella, and Bartonella spp.), nontuberculous mycobacteria, and M. tuberculosis. ${ }^{15)}$ Rifampicin exhibits bactericidal ability against actively dividing bacteria as well as those that occasionally metabolize for a short period, killing them more rapidly than isoniazid. ${ }^{16}$

Rifampicin was first used clinically in Italy in 1968 and has been the most important drug for the treatment of TB for approximately 50 years. Rifampicin in combination with anti-TB drugs has reduced the overall treatment duration. ${ }^{17)}$

\section{Pharmacokinetics and pharmacodynamics of rifampicin}

Rifampicin is well absorbed when taken orally and rapidly absorbed in the intestine during fasting but less so when taken with food. It is well distributed in most tissues and body fluids. As it is fat-soluble, it passes through the blood-brain barrier. It is metabolized in the liver and has a half-life of 3-4 hours. Since the half-life may be prolonged in patients with abnormal liver function, dose adjustment is necessary in patients with liver failure. However, no dose adjustment is required in patients with renal insufficiency, as only $13 \%-24 \%$ is excreted in the urine. ${ }^{15,18)}$

The bactericidal ability of rifampicin against $M$. tuberculosis depends on its concentration, and the most correlated pharmacokinetic/pharmacodynamic parameter is the area under the con- centration-time curve to minimum inhibitory concentration (MIC) ratio. Preventing the emergence of resistance is associated with the free peak concentration $(\mathrm{C}(\max ))$ to MIC ratio. ${ }^{19)}$

\section{Rifampicin dose for treating pediatric $T B$}

When using 4R for the treatment of LTBI in adults, the recommended dose of rifampicin is $10 \mathrm{mg} / \mathrm{kg}$. However, when children aged 3 months to 13 years (mean, 4 years) were administered a mean rifampicin dosage of $9.6 \mathrm{mg} / \mathrm{kg}$, they showed very low serum concentrations, with a mean maximum concentration (Cmax) of $4.9-6.9 \mu \mathrm{g} / \mathrm{mL}^{20)}$ The desirable Cmax of rifampicin suggested in healthy adults is $8-24 \mu \mathrm{g} /$ $\mathrm{mL}$. It is recommended that, if the Cmax is 6 or less, the dose of rifampicin should be increased. ${ }^{21)}$ In 2010, the World Health Organization (WHO) increased the dose of primary anti-TB drugs in children to improve treatment outcomes and recommended rifampicin doses of $15 \mathrm{mg} / \mathrm{kg}$ (range, 10-20 $\mathrm{mg} / \mathrm{kg}$; maximum dose, $600 \mathrm{mg} /$ day). ${ }^{22)}$ After the guideline change, one study compared rifampicin $10 \mathrm{mg} / \mathrm{kg}$ to $15 \mathrm{mg} /$ $\mathrm{kg}$ in 11 children under 2 years of age. When rifampicin was administered at $10 \mathrm{mg} / \mathrm{kg}$, the mean Cmax was $6.36 \mu \mathrm{g} / \mathrm{mL}$ $(4.45-8.27 \mu \mathrm{g} / \mathrm{mL})$, whereas at $15 \mathrm{mg} / \mathrm{kg}$, it was $11.7 \mu \mathrm{g} / \mathrm{mL}$ (8.7-14.7 $\mu \mathrm{g} / \mathrm{mL})$, thus reaching an appropriate therapeutic concentration with the latter. ${ }^{23)}$ However, in one study in which children aged $<10$ years (median age, 2.29 years) were given rifampicin 9-22 $\mathrm{mg} / \mathrm{kg}$, only 2/31 (6\%) of children attained the therapeutic concentration. ${ }^{24)}$ Moreover, in 2016, Bekker et al. ${ }^{25)}$ reported that when 39 infants aged $<12$ months (mean age, 6.6 months) were administered rifampicin $10.1-20.5 \mathrm{mg} / \mathrm{kg}$, the mean Cmax was $2.9 \mu \mathrm{g} / \mathrm{mL}$, much lower than expected. In this study, 2 rifampicin formulations were used in which infants receiving a rifampicin formulation administered at a lower dose had higher mean rifampicin concentrations than those receiving a higher dose. Thus, at least in this study, dose alone was not associated with Cmax.

In another study of 62 children with a median age of 5 years diagnosed with active $\mathrm{TB}$, the children received a median dose of $16 \mathrm{mg} / \mathrm{kg}$ (interquartile range [IQR], 13.8-19.8 mg/ $\mathrm{kg}$ ) of rifampicin. The median Cmax of rifampicin in the subjects was $6.3 \mu \mathrm{g} / \mathrm{mL}$ (IQR, 3.5-8.8 $\mu \mathrm{g} / \mathrm{mL}$ ); among the 51 subjects who received the dose range recommended by WHO, i.e., $15 \mathrm{mg} /$ $\mathrm{kg}$ (IQR, 10-20 mg/kg), only $21(41.2 \%)$ reached the target concentration. ${ }^{26}$ Aruldhas et al. ${ }^{27)}$ developed a population pharmacokinetic model using concentration-time data of rifampicin from 41 children aged 2-16 years diagnosed with pulmonary or lymph node TB. In a simulation using this model, $28.8 \%$ of children weighing 4-39 kg had a Cmax greater than $8 \mu \mathrm{g} / \mathrm{mL}$ after rifampicin 10.7 - to $18.7-\mathrm{mg} / \mathrm{kg}$ administration. However, when rifampicin $35-40 \mathrm{mg} / \mathrm{kg}$ was administered to children weighing 6-30 kg, $74.2 \%$ had a Cmax greater than 8 $\mu \mathrm{g} / \mathrm{mL}$.

In a pediatric study, children with low blood levels of rifampicin were more likely to have poor treatment outcomes, and exposure to rifampicin was the lowest in children with a 
low body weight or human immunodeficiency virus (HIV) coinfection. ${ }^{28)}$ Another study of 113 pediatric TB patients in Ghana reported that HIV-infected pediatric TB patients had lower exposure to rifampicin, i.e., a lower Cmax and a lower area under the concentration-time curve from 0 to 8 hours (area under the curve $=0-8$ ) than children with TB alone. ${ }^{29)}$

Other factors involved in the bioavailability of rifampicin include the characteristics of the raw materials, additives of formulations, diversity of manufacturing processes, degradation in the gastrointestinal tract, and inherent variability in drug absorption and metabolism. ${ }^{30)}$

Based on the above-described results, the recommended dose of rifampicin in the treatment of LTBI has increased to achieve blood concentrations above the MIC of M. tuberculosis in HIVinfected and non-HIV-infected children. The 2018 American Academy of Pediatrics (AAP) guidelines increased the daily dose of rifampicin to $15-20 \mathrm{mg} / \mathrm{kg}$ for treating TB in children aged $0-15$ years. The guidelines also added that many experts recommend rifampicin $20-30 \mathrm{mg} / \mathrm{kg} /$ day for the treatment of $\mathrm{TB}$ in infants and toddlers (i.e., $0-2$ years) and children of any age with severe TB. ${ }^{31)}$ In 2020, the CDC guidelines for LTBI recommended that children (aged $2-17$ years) receive rifampicin $15-20 \mathrm{mg} / \mathrm{kg}$ for $4 \mathrm{R}$ and that infants and toddlers (aged 0-2 years) receive $20-30 \mathrm{mg} / \mathrm{kg}$ while referring to the AAP guidelines in the footnotes. ${ }^{9)}$ The WHO guideline published in 2020 recommends rifampicin $10 \mathrm{mg} / \mathrm{kg} /$ day for the $4 \mathrm{R}$ regimen for children aged $>10$ years and rifampicin $15 \mathrm{mg} / \mathrm{kg} /$ day (range, $10-20 \mathrm{mg} / \mathrm{kg} /$ day) for children aged $<10$ years. ${ }^{32}$ Considering the relationship between the administered dose of rifampicin and its serum concentrations in previous studies, it may not be possible to achieve an adequate blood concentration of rifampicin in very young children at the dose recommended by the WHO. We suggest that very young children (age, 0-2 years) be given rifampicin $20-30 \mathrm{mg} / \mathrm{kg}$ and children aged $2-10$ be given rifampicin $15-20 \mathrm{mg} / \mathrm{kg}$.

\section{Adverse effects}

Rifampicin is an anti-TB drug with relatively few major adverse effects. Its toxicity can be largely divided into 2 types: hepatotoxicity and immunoallergic effects. Hepatotoxicity due to rifampicin has a much lower incidence than that caused by isoniazid. ${ }^{33,34)}$ Administering rifampicin resulted in a transient elevation of liver enzyme levels within the first few weeks in $10 \%-20 \%$ of patients, but in most cases no special measures were required. ${ }^{35-37)}$ Although rifampicin alone has a low risk of hepatotoxicity, a review published in 1991 reported an increased incidence of clinical hepatitis when isoniazid and rifampicin were administered to children compared with isoniazid alone. Although few studies have reported very high rates of clinical hepatitis, children receiving isoniazid and rifampicin were 4 times more likely to develop hepatitis than those receiving isoniazid alone. ${ }^{33)}$ However, the mechanism of this phenomenon is unknown.

The immunoallergic effects associated with intermittent therapy range from minor (skin, digestive system, or flu-like syndrome) to major (hemolytic anemia, shock, or acute kidney injury). ${ }^{36,38)}$ When rifampicin is administered daily, the rash usually appears at the beginning of treatment; most reactions are mild and transient and improve with observation without drug discontinuation. ${ }^{36,39)}$ Flu-like syndrome rarely occurs with daily rifampicin therapy, but it can be seen with intermittent dosing, especially once-weekly dosing. ${ }^{36}$ Gastrointestinal symptoms may include anorexia, nausea, mild abdominal pain, and vomiting, but most are mild. Gastrointestinal symptoms are also more common in patients receiving intermittent therapy than in those receiving daily therapy. ${ }^{40)}$ Hematological adverse events are rare, and rifampicin-induced thrombocytopenia is associated with antiplatelet antibodies and improves upon drug discontinuation. ${ }^{41)}$

\section{Drug interactions}

Rifampicin induces cytochrome P450 (CYP450), drug transport protein expression, and drug-metabolizing enzymes such as uridine 5'-diphospho-glucuronyltransferases and sulfotransferases. ${ }^{42,43)}$ Drugs such as oral anticoagulants, antifungal drugs, and oral contraceptives, although not used frequently in children, interact with rifampicin. In addition, since rifampicin is a potent CYIP3A4 inducer, it reduces plasma concentrations of the nonnucleoside reverse transcriptase inhibitor and the protease inhibitor, CYP3A4 substrates, a problem in people receiving rifampicin for HIV-associated or preventive TB treatment. ${ }^{42,44)}$ CYP3A4 inducers may decrease serum concentrations of corticosteroids such as dexamethasone and methylprednisolone. Therefore, when prescribing dexamethasone or prednisolone to patients receiving rifampicin, it is necessary to consider increasing the corticosteroid dose and closely monitoring whether the corticosteroid efficacy decreases. ${ }^{43)}$

Rifampicin is also a potent inducer of CYP1A2 and CYP2C19 and an intermediate inducer of CYP2B6, CYP2C8, and CYP2C9. Therefore, antiretroviral agents that are metabolized by one of these enzymes are also affected. ${ }^{45}$ Since there have been few evaluations of the efficacy of $4 \mathrm{R}$ in patients with LTBI and HIV coinfection, 4R is recommended for patients without HIV infection. ${ }^{9)}$ However, a recent study in adult HIV patients reported that $4 \mathrm{R}$ was safe and effective even in HIV-infected patients. ${ }^{46}$

\section{Completion rate, safety, and efficacy of $4 R$ versus $9 \mathrm{H}$ for treating $\mathrm{LTBI}$ in children}

\section{Completion rate}

Since the late 1950s, isoniazid for 6-12 months has been used to treat LTBI in children. ${ }^{47)}$ In 2000, American Thoracic Society recommended $9 \mathrm{H}$ for children and adolescents as the preferred regimen based on the results that 12 months of isoniazid was more effective than 6 months of isoniazid and that the maximal beneficial effect of isoniazid is achieved by 9 months in HIV- 
uninfected adults. ${ }^{8)}$ Since the Korean guidelines for TB were first published in 2011, $9 \mathrm{H}$ has been among the main regimens for treating TB in children. As such, $9 \mathrm{H}$ has long been used effectively for treating LTBI in children, but the completion rate is low due to the long administration period. ${ }^{47)}$ In children, the completion rate of $9 \mathrm{H}$ was approximately $50 \%$, especially low among self-administration cases. ${ }^{48,49)}$ The program for immigrant children reported a lower completion rate, with a $68 \%$ initiation rate but only $12 \%$ completion rate. ${ }^{50)}$ Even in adults, the completion rate of $9 \mathrm{H}$ was reportedly only $46.5 \%$ $50 \%{ }^{51,52)}$ Very limited data are available about the completion rate of LTBI in Korean children. In one institutional study, 13 of 15 patients prescribed $9 \mathrm{H}$ at the beginning of treatment were reportedly completed it. ${ }^{53)}$

We searched the MEDLINE, Embase, Web of Science, and Cochrane databases to identify studies that compared completion rates and safety between $4 \mathrm{R}$ and $9 \mathrm{H}$ in children. One randomized controlled trial (RCT) and 3 retrospective studies compared the $4 \mathrm{R}$ and $9 \mathrm{H}$ completion rates children (Table 1). In the RCT, 4R had a significantly higher completion rate than $9 \mathrm{H}$ (Table 1). ${ }^{54)}$ In the retrospective studies, when self-administered, 4R showed a better completion rate than $9 \mathrm{H}(93 \%$ vs. $62 \%) .{ }^{55)}$ The authors conducted another study comparing $9 \mathrm{H}, 3 \mathrm{HP}$, and $4 \mathrm{R}$; in that study, the completion rate of $4 \mathrm{R}$ was higher than that of $9 \mathrm{H}$ when self-administered ( $83.5 \%$ vs. $52.6 \%){ }^{56}$ )

Three prospective or retrospective cohort studies compared 4R and $9 \mathrm{H}$, including adults and children, among the study subjects (Table 2). ${ }^{57-59)}$ These studies consistently reported that $4 \mathrm{R}$ had a higher completion rate than $9 \mathrm{H}$.

\section{Safety}

Children are generally more tolerant of anti-TB drugs than adults. Although there are other factors contributing to this phenomenon, it may be in part because drug levels (exposure) are actually lower, as they were often underdosed in these older studies. There are few reports on drug discontinuation due to fatal hepatotoxicity or side effects during the treatment of LTBI in children. In a recent RCT comparing the safety of $4 \mathrm{R}$ and $9 \mathrm{H}$ in children, there were no cases of drug discontinuation due to adverse reactions in either group. The number of patients complaining of minor adverse events did not differ between groups (Table 1). ${ }^{54)}$ In a cohort study of $4 \mathrm{R}, 9 \mathrm{H}$, and $3 \mathrm{HP}$ regimens, adverse events were more common in the $9 \mathrm{H}$ treatment group than in the $3 \mathrm{HP}$ or $4 \mathrm{R}$ treatment groups. The most common adverse reaction was abdominal pain, and only 2 of 667 patients $(0.3 \%)$ had elevated liver enzyme levels. One patient in the $9 \mathrm{H}$ group had an increased liver enzyme level of $\geq 1,000 \mathrm{U} / \mathrm{L}$ after taking the medicine for 8 months. ${ }^{56}$ ) A retrospective study compared $4 \mathrm{R}$ and $9 \mathrm{H}$ and reported no intergroup difference in the incidence of adverse events. Hepatitis occurred in $0.5 \%$ of 404 patients. ${ }^{55)}$ In the study reported by Gaensbauer et al. ${ }^{60)}$ comparing $4 \mathrm{R}$ and $9 \mathrm{H}$, the proportions of drug discontinuation cases due to adverse drug reactions were $1.5 \%$ in $4 \mathrm{R}$ and $0.7 \%$ in $9 \mathrm{H}$, and no significant intergroup difference was observed. There were no cases of symptomatic hepatotoxicity in either group.

\section{Efficacy of $4 \mathrm{R}$ versus $9 \mathrm{H}$}

LTBI treatment began with isoniazid monotherapy, and it was efficacious at preventing 70\%-90\% of active TB cases in children. When the drug was taken consistently, the treatment efficacy was reportedly $>90 \%{ }^{61-63)}$ To confirm whether the LTBI treatment was efficacious and prevented the progression to TB disease in patients with LTBI, it is necessary to conduct a follow-up observation for a certain period after treatment. In this regard, Diallo et al. ${ }^{54)}$ followed up patients for 16 months

\section{Table 1. Studies comparing 4R to other latent tuberculosis treatment regimens administered to children only}

\begin{tabular}{|c|c|c|c|c|c|c|c|c|c|c|c|c|}
\hline \multirow[t]{2}{*}{ Study } & \multicolumn{2}{|c|}{ Population } & \multirow[t]{2}{*}{$\begin{array}{l}\text { Compa- } \\
\text { rator } \\
\text { regimen }\end{array}$} & \multirow[t]{2}{*}{ Country } & \multirow[t]{2}{*}{ Study design } & \multirow[t]{2}{*}{$\begin{array}{l}\text { Follow-up } \\
\text { duration }\end{array}$} & \multirow[t]{2}{*}{$\begin{array}{l}\text { Period } \\
\text { of } \\
\text { study }\end{array}$} & \multicolumn{3}{|c|}{$\begin{array}{l}\text { Permanent drug } \\
\text { discontinuation } \\
\text { because of } \\
\text { treatment related } \\
\text { adverse events, } \\
\text { n/N }\end{array}$} & \multicolumn{2}{|c|}{$\begin{array}{c}\text { Active TB } \\
\text { progression, } \\
n\end{array}$} \\
\hline & $\begin{array}{l}\text { Median } \\
\text { age }\end{array}$ & $\begin{array}{l}\text { PLHIV, } \\
\mathrm{n}(\%)\end{array}$ & & & & & & $4 \mathrm{R}$ & $4 \mathrm{R}$ & $\begin{array}{l}\text { Com- } \\
\text { parator }\end{array}$ & $4 \mathrm{R}$ & $\begin{array}{l}\text { Com- } \\
\text { parator }\end{array}$ \\
\hline $\begin{array}{l}\text { Diallo et al. }^{54)} \\
(2018)\end{array}$ & 10.2 & $0(0)$ & $9 \mathrm{H}$ & $\begin{array}{l}\text { Australia, Benin, } \\
\text { Brazil, Canada, } \\
\text { Ghana, Guinea, } \\
\text { Indonesia }\end{array}$ & $\begin{array}{l}\text { Multicenter, randomly } \\
\text { assigned open-label } \\
\text { trial }\end{array}$ & $\begin{array}{l}\text { 16-Month follow- } \\
\text { up after rando- } \\
\text { mization }\end{array}$ & $\begin{array}{l}2011- \\
2014\end{array}$ & $360 / 422(85.3)$ & $0 / 422$ & $0 / 407$ & $\begin{array}{l}\text { 0/562 } \\
\text { Person- } \\
\text { years }\end{array}$ & $\begin{array}{l}2 / 542 \\
\text { Person- } \\
\text { years }\end{array}$ \\
\hline $\begin{array}{l}\text { Gaensbauer } \\
\text { et al. }{ }^{60)} \\
(2018)\end{array}$ & $\begin{array}{l}\text { 4R: } 13 \\
9 \mathrm{H}: 11\end{array}$ & NR & $9 \mathrm{H}$ & United States & $\begin{array}{l}\text { Single center, retrospec- } \\
\text { tive study }\end{array}$ & NA & $\begin{array}{l}2006- \\
2015\end{array}$ & $330 / 395$ (83.5) & $6 / 395$ & $6 / 779$ & NR & NR \\
\hline \multirow{2}{*}{$\begin{array}{l}\text { Cruz and } \\
\text { Starke }^{56)} \\
(2018)\end{array}$} & \multirow[t]{2}{*}{8.0} & \multirow[t]{2}{*}{$0(0)$} & & \multirow[t]{2}{*}{ USA } & \multirow[t]{2}{*}{$\begin{array}{l}\text { Single center, retrospec- } \\
\text { tive cohort study }\end{array}$} & \multirow[t]{2}{*}{ NR } & \multirow[t]{2}{*}{$\begin{array}{l}2014- \\
2017\end{array}$} & \multirow{2}{*}{$\begin{array}{r}\text { SAT, } 66 / 79(83.5) \\
\text { ESAT, 16/18 (88.9); } \\
\text { DOPT, 34/35 (97.1) }\end{array}$} & \multirow[t]{2}{*}{$1 / 132$} & $\begin{array}{c}9 \mathrm{H} \\
8 / 252\end{array}$ & \multirow[t]{2}{*}{0} & \multirow[t]{2}{*}{1} \\
\hline & & & $3 \mathrm{HP}$ & & & & & & & $\begin{array}{l}3 \mathrm{HP} \\
4 / 283\end{array}$ & & \\
\hline $\begin{array}{l}\text { Cruz and } \\
\text { Starke } \\
(2014)\end{array}$ & 6.6 & NR & $9 \mathrm{H}$ & USA & $\begin{array}{l}\text { Single center, retrospec- } \\
\text { tive cohort study }\end{array}$ & 6-48 Months & $\begin{array}{l}2010- \\
2013\end{array}$ & $\begin{array}{l}\text { SAT, } 54 / 57(93) \\
\text { ESAT, } 13 / 13(100) \\
\text { DOPT, 10/10 (100) }\end{array}$ & $1 / 80$ & $6 / 324$ & 0 & 0 \\
\hline
\end{tabular}

4R, 4 months of rifampin; PLHIV, people living with human immunodeficiency virus; TB, tuberculosis; 9H, 9 months of isoniazid; NA, not available; NR, not reported; 3HP, 3 months of isoniazid plus rifapentine; SAT, self-administered therapy; ESAT, enhanced self-administered therapy (medication delivered to the home monthly from the public health center with periodic reminder calls and administered to the child by family members); DOPT, directly observed preventive therapy 
Table 2. Outcomes of studies that compared $4 \mathrm{R}$ to other latent tuberculosis treatment regimens administered to children and adults

\begin{tabular}{|c|c|c|c|c|c|c|c|c|c|c|c|c|c|}
\hline \multirow[b]{2}{*}{ Study } & \multirow{2}{*}{$\begin{array}{c}\text { No. of } \\
\text { total } \\
\text { cohorts }\end{array}$} & \multicolumn{2}{|c|}{ Population } & \multirow{2}{*}{$\begin{array}{l}\text { Compa- } \\
\text { rator } \\
\text { regimen }\end{array}$} & \multirow[b]{2}{*}{ Country } & \multirow[b]{2}{*}{ Study design } & \multirow{2}{*}{$\begin{array}{l}\text { Period } \\
\text { of } \\
\text { study }\end{array}$} & \multicolumn{2}{|c|}{$\begin{array}{c}\text { Completion rates, } \\
\mathrm{n} / \mathrm{N}(\%)\end{array}$} & \multicolumn{2}{|c|}{$\begin{array}{l}\text { Safety, following results from a drug } \\
\text { adverse events, } \mathrm{n} / \mathrm{N}(\%)\end{array}$} & \multicolumn{2}{|c|}{$\begin{array}{c}\text { Active TB } \\
\text { progression, } \mathrm{n} / \mathrm{N}\end{array}$} \\
\hline & & $\begin{array}{c}\text { Age } \\
\text { distribution, } \\
\text { year: number }\end{array}$ & $\begin{array}{l}\text { PLHIV, } \\
\mathrm{n}(\%)\end{array}$ & & & & & $4 R$ & Comparator & $4 \mathrm{R}$ & Comparator & $4 \mathrm{R}$ & Comparator \\
\hline $\begin{array}{l}\text { Lardizabal } \\
\quad \text { et al. }{ }^{57)} \\
(2006)\end{array}$ & 474 & $\begin{array}{l}1-24: 348 \\
25-34: 48 \\
35-44: 49 \\
\geq 45: 29\end{array}$ & NR & $9 \mathrm{H}$ & USA & $\begin{array}{l}\text { Retrospective } \\
\text { cohort }\end{array}$ & $\begin{array}{l}2000- \\
2003\end{array}$ & $\begin{array}{c}210 / 261 \\
(80.5)\end{array}$ & $\begin{array}{c}113 / 213 \\
(53.1)\end{array}$ & $\begin{array}{l}\text { Discontinuation: } \\
\text { 8/261 (3.1) }\end{array}$ & $\begin{array}{l}\text { Discontinuation: } \\
\text { 13/213 (6.1) }\end{array}$ & $0 / 261$ & $1 / 213$ \\
\hline $\begin{array}{l}\text { Page et al. }{ }^{58)} \\
\quad(2006)\end{array}$ & 2,149 & $\begin{array}{l}<18: 254 \\
\text { 18-35: } 1,086 \\
>35: 809\end{array}$ & $\begin{array}{c}12 \\
(1.1)\end{array}$ & $9 \mathrm{H}$ & USA & $\begin{array}{l}\text { Retrospective } \\
\text { cohort }\end{array}$ & $\begin{array}{l}1999- \\
2004\end{array}$ & $\begin{array}{l}987 / 1,379 \\
(71.6)\end{array}$ & $\begin{array}{l}405 / 770 \\
(52.6)\end{array}$ & $\begin{array}{l}\text { Discontinuation: } \\
23 / 1229(1.9)\end{array}$ & $\begin{array}{l}\text { Discontinuation: } \\
31 / 670(4.6)\end{array}$ & $1 / 1,379$ & $0 / 770$ \\
\hline $\begin{array}{l}\text { Ronald } \\
\text { et al. }{ }^{59, \text { a) }} \\
\text { (2020) }\end{array}$ & 10,559 & $\begin{array}{l}0-19: 2,359 \\
20-34: 3,314 \\
35-49: 2,777 \\
50-64: 1,380 \\
\geq 65: 729\end{array}$ & $\begin{array}{c}108 \\
(0.01)\end{array}$ & $9 \mathrm{H}$ & Canada & $\begin{array}{l}\text { Retrospective } \\
\text { cohort }\end{array}$ & $\begin{array}{l}2003- \\
2007\end{array}$ & $\begin{array}{c}468 / 875 \\
(53.5)\end{array}$ & $\begin{array}{l}3,573 / 9,684 \\
(36.9)\end{array}$ & $\begin{array}{l}\text { Severe hepatic } \\
\text { adverse events } \\
1 / 875(0.001)\end{array}$ & $\begin{array}{l}\text { Severe hepatic } \\
\text { adverse events } \\
15 / 9,684 \\
(0.0015)^{b)}\end{array}$ & NR & NR \\
\hline
\end{tabular}

4R: 4 months of rifampin; PLHIV: people living with human immunodeficiency virus; NR, not reported; $9 H$ : 9 months of isoniazid; TB: tuberculosis.

a) The studies by Lardizabal and Page did not report age-stratified results. The study by Ronald et al. stratified results by age and comorbidity (defined as one or more hospitalizations within one year prior to the initiation of latent tuberculosis treatment). Among patients aged 0-19 years with comorbidities, the treatment completion rate of the 4R group was $28.6 \%$, while that of the $9 \mathrm{H}$ group was $19.4 \%$; no cases of severe liver disease occurred in either group. Among patients aged $0-19$ years without comorbidities, the treatment completion rate of the $4 \mathrm{R}$ group was $61.6 \%$, while that of the $9 \mathrm{H}$ group was $33.8 \%$. Severe liver disease occurred in 2 patients (0.09\%) without comorbidities in the $9 \mathrm{H}$ group. ${ }^{\text {b) }}$ Included liver transplants ( $n=2)$ and hospitalizations ending in death $(n=1)$

after enrollment. During the observation period, there were no cases of TB in the $4 \mathrm{R}$ treatment group versus 2 cases in the $9 \mathrm{H}$ treatment group. The remaining studies listed in Table 1 were retrospective and observational; hence, it was difficult to confirm the treatment efficacy. However, there are a few reports of cases progressing to active $\mathrm{TB}$, and no intergroup difference was confirmed. Rifampicin monotherapy was not inferior to $9 \mathrm{H}$ in adult studies. ${ }^{64)}$ In a network meta-analysis conducted to confirm the effectiveness of various LTBI treatment regimens, the daily administration of rifampicin for 3 or 4 months (odds ratio [OR], $0.25 ; 95 \%$ credible interval [CrI], 0.11-0.57) was confirmed effective at preventing TB versus no treatment. ${ }^{65}$ ) Also, 9H (OR, 0.46 [95\% CrI, 0.22-0.95]) and 3 or 4 months of daily isoniazid plus rifampicin (OR, 0.33 [95\% CrI, 0.20-0.54]) appeared efficacious at reducing active $\mathrm{TB}$ versus no treatment.

\section{Cost-effectiveness of $4 R$}

In Korea, isoniazid costs 15 won (Korean won [KRW]; 0.01 United State dollar [USD]) per $100 \mathrm{mg}$ tablet, while rifampicin costs $104 \mathrm{KRW}$ (0.09 USD) per 150-mg tablet. According to the Korean guidelines for TB, daily therapy for LTBI in children requires $10 \mathrm{mg} / \mathrm{kg}$ of body weight for isoniazid and $15 \mathrm{mg} / \mathrm{kg}$ of body weight for rifampicin. Therefore, for the treatment of LTBI in a child weighing $10 \mathrm{~kg}$, the cost is 4,050 KRW (3.54 USD) for $9 \mathrm{H}$ and $12,480 \mathrm{KRW}$ (10.89 USD) for 4R. In terms of drug price alone, $4 \mathrm{R}$ costs more, but neither regimen is burdensome in Korea. In children, blood tests are generally not routinely performed during LTBI treatment, and drug-related side effects rarely occur during treatment. During LTBI treatment, a monthly hospital visit for clinical observation of adverse drug reactions is recommended. ${ }^{6}$ According to this recommendation, after the initiation of treatment, $9 \mathrm{H}$ requires 9 hospital visits and $4 \mathrm{R}$ requires 4 hospital visits. Considering all healthcare costs, including the drug price, all testing, and follow-up visits, $4 \mathrm{R}$ will cost less. Bastos et $\mathrm{al}{ }^{66}$ ) reported that $4 \mathrm{R}$ was less expensive than 9H in high-income, middle-income, and African countries.

\section{Rifampicin susceptibility to rifampicin after rifampicin monotherapy for LTBI}

Rifampicin is among the most important drugs for the treatment of TB. However, resistance could be a problem if patients progress to TB disease after LTBI treatment with rifampicin alone. Although there are few reports on this issue, a systematic review concluded that there is no evidence indicating that more rifampicin-resistant $M$. tuberculosis is detected in patients who develop active TB after preventive treatment with a rifamycin-based regimen. ${ }^{67)}$ In a study by Page et al., ${ }^{58)} 1$ of 1,379 people prescribed $4 \mathrm{R}$ was diagnosed with cervical lymphadenitis 1 year later, and the M. tuberculosis isolate was susceptible to rifampicin. In another study of 679 patients with silicosis in Hong Kong, 15 treated with rifampicin alone during a 5-year follow-up period progressed to active TB disease, and all $15 \mathrm{M}$. tuberculosis isolates were susceptible to rifampicin. ${ }^{11)}$

\section{Nitrosamine contaminants in rifampicin}

In August 2020, the U.S. Food and Drug Administration announced that nitrosamine impurities were detected and investigated in rifampicin and rifapentine sold in the United States. ${ }^{68)}$ In fact, the 1-methyl-4-nitrosopiperazine (MNP) detected in rifampicin belongs to the nitrosamine class of compounds, some of which are classified as possible carcinogens in humans based on carcinogenicity studies in rodents. Accordingly, some experts have recommended that children receive only $9 \mathrm{H}$ for latent TB treatment until additional data are available. ${ }^{69)}$ 
In all products distributed in Korea, the MNP content of rifampicin distributed in Korea was 1.68-6.07 ppm, higher than the provisional management standard $(0.16 \mathrm{ppm}){ }^{70)} \mathrm{In}$ the United States, when the MNP content in rifampicin is $<5$ $\mathrm{ppm}$, distribution is temporarily allowed to prevent a shortage of drugs essential for TB treatment. In Korea, the Ministry of Food and Drug Safety also allowed the distribution of rifampicin to consider the following factors. Rifampicin is an essential drug for the treatment of TB, which can be life-threatening, alternative drugs are lacking; the health effect is not significant considering the results of human impact evaluation; and its distribution is allowed in other countries. Manufacturers are trying to remove nitrosamine impurities and meet the standards of the Ministry of Food and Drug Safety. Once these standards are satisfied, then $4 \mathrm{R}$ can be safely administered again. ${ }^{70)}$

\section{Conclusions}

The $9 \mathrm{H}$ regimen has been used effectively for the treatment of LTBI in children for over 20 years. However, patient compliance was poor due to the long treatment duration. According to a recent randomized trial of treating LTBI in children, the $4 \mathrm{R}$ regimen had a higher completion rate than the $9 \mathrm{H}$ regimen with comparable safety in children. Its efficacy at preventing TB was also similar to that of $9 \mathrm{H}$ when reports published to date were summarized. A shorter treatment duration will increase patient compliance, and through greater compliance, it is possible to prevent progression to TB disease in more patients. This will be an important element of effort to bring us closer to our goal of eradicating TB.

\section{Footnotes}

Conflicts of interest: No potential conflict of interest relevant to this article was reported.

Funding: This study received no specific grant from any funding agency in the public, commercial, or not-for-profit sectors.

ORCID:

Chi Eun Oh @ https://orcid.org/0000-0002-0439-8170

Dick Menzies @ https://orcid.org/0000-0003-1601-4514

\section{References}

1. Houben RM, Dodd PJ. the global burden of latent tuberculosis infection: a re-estimation using mathematical modelling. PLoS Med 2016;13: e1002152.

2. Neuenschwander BE, Zwahlen M, Kim SJ, Engel RR, Rieder HL. Trends in the prevalence of infection with mycobacterium tuberculosis in Korea from 1965 to 1995: an analysis of seven surveys by mixture models. Int J Tuberc Lung Dis 2000;4:719-29.
3. Korean National Tuberculosis Association. 7th Korea National Health and Nutrition Examination Survey: Tuberculin Survey Support and Quality Control. Seoul (Korea): Korea Centers for Disease Control and Prevention, 2017.

4. Go U, Park M, Kim UN, Lee S, Han S, Lee J, et al. Tuberculosis prevention and care in Korea: evolution of policy and practice. J Clin Tuberc Other Mycobact Dis 2018;11:28-36.

5. Cho KS. Tuberculosis control in the Republic of Korea. Epidemiol Health 2018;40:e2018036.

6. Song JH, Huh K, Chung DR. Modern history of tuberculosis in Korea. Infect Chemother 2019;51:414-26.

7. Korea Centers for Disease Control and Prevention. Korean Guidelines for Tuberculosis. 4th ed. Cheongiu (Korea): Joint Committee for the Revision of Korean Guidelines for Tuberculosis and Korea Centers for Disease Control \& Prevention, 2020.

8. Targeted tuberculin testing and treatment of latent tuberculosis infection. American Thoracic Society. MMWR Recomm Rep 2000;49(RR-6):151.

9. Sterling TR, Njie G, Zenner D, Cohn DL, Reves R, Ahmed A, et al. Guidelines for the treatment of latent tuberculosis infection: recommendations from the National Tuberculosis Controllers Association and CDC, 2020. MMWR Recomm Rep 2020;69:1-11.

10. Lincoln EM. The effect of antimicrobial therapy on the prognosis of primary tuberculosis in children. Am Rev Tuberc 1954;69:682-9.

11. A double-blind placebo-controlled clinical trial of three antituberculosis chemoprophylaxis regimens in patients with silicosis in Hong Kong. Hong Kong Chest Service/Tuberculosis Research Centre, Madras/British Medical Research Council. Am Rev Respir Dis 1992;145:36-41.

12. Lobue P, Menzies D. Treatment of latent tuberculosis infection: an update. Respirology 2010;15:603-22.

13. Sensi P. History of the development of rifampin. Rev Infect Dis $1983 ; 5$ Suppl 3:S402-6.

14. Wehrli W. Rifampin: mechanisms of action and resistance. Rev Infect Dis 1983;5 Suppl 3:S407-11.

15. Maslow MJ, Portal-Celhay C. Rifamycins. In: Bennett JE, Dolin R, editors. Mandell, Douglas, and Bennett's principles and practice of infectious diseases. 9th ed. Philadelphia (PA): Elsevier, Inc., 2020;e4:33749.

16. Dickinson JM, Mitchison DA. Experimental models to explain the high sterilizing activity of rifampin in the chemotherapy of tuberculosis. Am Rev Respir Dis 1981;123(4 Pt 1):367-71.

17. Fox W. Whither short-course chemotherapy? Br J Dis Chest 1981;75: 331-57.

18. Alsayyed B. Rifampin. Pediatr Rev 2004;25:216-7.

19. Gumbo T, Louie A, Deziel MR, Liu W, Parsons LM, Salfinger M, et al. Concentration-dependent Mycobacterium tuberculosis killing and prevention of resistance by rifampin. Antimicrob Agents Chemother 2007; 51:3781-8

20. Schaaf HS, Willemse M, Cilliers K, Labadarios D, Maritz JS, Hussey GD, et al. Rifampin pharmacokinetics in children, with and without human immunodeficiency virus infection, hospitalized for the management of severe forms of tuberculosis. BMC Med 2009;7:19.

21. Peloquin CA. Therapeutic drug monitoring in the treatment of tuberculosis. Drugs 2002;62:2169-83.

22. World Health Organization. Rapid advice: treatment of tuberculosis in children [Internet]. Geneva (Switzerland): World Health Organization; 2010 [cited 2021 Jul 30]. Available from: https://apps.who.int/iris/ handle/10665/44444.

23. Thee S, Seddon JA, Donald PR, Seifart HI, Werely CJ, Hesseling AC, et al. Pharmacokinetics of isoniazid, rifampin, and pyrazinamide in children younger than two years of age with tuberculosis: evidence for implementation of revised World Health Organization recommendations. Antimicrob Agents Chemother 2011;55:5560-7.

24. Hiruy H, Rogers Z, Mbowane C, Adamson J, Ngotho L, Karim F, et al. Subtherapeutic concentrations of first-line anti-TB drugs in South African children treated according to current guidelines: the PHATISA study. J Antimicrob Chemother 2015;70:1115-23. 
25. Bekker A, Schaaf HS, Draper HR, van der Laan L, Murray S, Wiesner $\mathrm{L}$, et al. Pharmacokinetics of rifampin, isoniazid, pyrazinamide, and ethambutol in infants dosed according to revised WHO-recommended treatment guidelines. Antimicrob Agents Chemother 2016;60:2171-9.

26. Kwara A, Enimil A, Gillani FS, Yang H, Sarfo AM, Dompreh A, et al. Pharmacokinetics of first-line antituberculosis drugs using WHO revised dosage in children with tuberculosis with and without hiv coinfection. J Pediatric Infect Dis Soc 2016;5:356-65.

27. Aruldhas BW, Hoglund RM, Ranjalkar J, Tarning J, Mathew SK, Verghese VP, et al. Optimization of dosing regimens of isoniazid and rifampicin in children with tuberculosis in India. Br J Clin Pharmacol 2019;85:644-54.

28. Guiastrennec B, Ramachandran G, Karlsson MO, Kumar AKH, Bhavani PK, Gangadevi NP, et al. Suboptimal antituberculosis drug concentrations and outcomes in small and HIV-coinfected children in India: recommendations for dose modifications. Clin Pharmacol Ther 2018;104:733-41.

29. Antwi S, Yang H, Enimil A, Sarfo AM, Gillani FS, Ansong D, et al. Pharmacokinetics of the first-line antituberculosis drugs in ghanaian children with tuberculosis with or without HIV coinfection. Antimicrob Agents Chemother 2017;61:e01701-16.

30. World Health Organization. Communicable Diseases Cluster. Fixeddose combination tablets for the treatment of tuberculosis: report of an informal meeting held in Geneva, Tuesday, 27 April 1999 [Internet]. Geneva (Switzerland): World Health Organization; 1999 [cited 2021 Jul 30]. Available from: https://apps.who.int/iris/handle/10665/65981.

31. American Academy of Pediatrics. Tuberculosis. In: Kimberlin DW, Brady MT, Jackson MA, Long SS, editors. Red book: 2018 report of the Committee on Infectious Diseases. 31st ed. Itasca: American Academy of Pediatrics, 2018:829-53.

32. WHO operational handbook on tuberculosis (Module 1 - Prevention): tuberculosis preventive treatment [Internet]. Geneva (Switzerland): World Health Organization; 2020 [cited 2021 Jul 30] Available from:. https:// apps.who.int/iris/bitstream/handle/10665/331525/9789240002906eng.pdf.

33. Steele MA, Burk RF, DesPrez RM. Toxic hepatitis with isoniazid and rifampin. A meta-analysis. Chest 1991;99:465-71.

34. Sanders WE Jr. Rifampin. Ann Intern Med 1976;85:82-6.

35. LiverTox: Clinical and research information on drug-induced liver injury [Internet]. Bethesda (MD): National Institute of Diabetes and Digestive and Kidney Diseases; 2012- [updated 2018 Jun 10; cited 2021 Jul 30] Available from: https://www.ncbi.nlm.nih.gov/books/NBK548314/.

36. Girling DJ. Adverse reactions to rifampicin in antituberculosis regimens. J Antimicrob Chemother 1977;3:115-32.

37. Baron DN, Bell JL. Serum enzyme changes in patients receiving antituberculosis therapy with rifampicin or p-aminosalicylic acid, plus isoniazid and streptomycin. Tubercle 1974;55:115-20.

38. Grosset J, Leventis S. Adverse effects of rifampin. Rev Infect Dis 1983;5 Suppl 3:S440-50.

39. Villarino ME, Ridzon R, Weismuller PC, Elcock M, Maxwell RM, Meador J, et al. Rifampin preventive therapy for tuberculosis infection: experience with 157 adolescents. Am J Respir Crit Care Med 1997;155: $1735-8$.

40. A controlled clinical trial of daily and intermittent regimens of rifampicin plus ethambutol in the retreatment of patients with pulmonary tuberculosis in Hong Kong. A Hong Kong Tuberculosis Treatment Services/ Brompton Hospital/British Medical Research Council investigation. Tubercle 1974;55:1-27.

41. Mehta YS, Jijina FF, Badakere SS, Pathare AV, Mohanty D. Rifampicininduced immune thrombocytopenia. Tuber Lung Dis 1996;77:558-62.

42. Semvua HH, Kibiki GS, Kisanga ER, Boeree MJ, Burger DM, Aarnoutse R. Pharmacological interactions between rifampicin and antiretroviral drugs: challenges and research priorities for resource-limited settings. Ther Drug Monit 2015;37:22-32.

43. Baciewicz AM, Chrisman CR, Finch CK, Self TH. Update on rifampin, rifabutin, and rifapentine drug interactions. Curr Med Res Opin 2013; 29:1-12.

44. World Health Organization. Updated recommendations on first-line and second-line antiretroviral regimens and post-exposure prophylaxis and recommendations on early infant diagnosis of HIV: interim guidelines: supplement to the 2016 consolidated guidelines on the use of antiretroviral drugs for treating and preventing HIV infection [Internet]. Geneva (Switzerland): World Health Organization; 2008 [cited 2021 Jul 30]. Available from: https://apps.who.int/iris/handle/10665/277395.

45. U.S. Food and Drug Administration. Drug development and drug interactions | Table of substrates, inhibitors and inducers [Internet]. Silver Spring (MD): U.S. Food and Drug Administration; 2021 [cited 2021 Jul 30]. Available from: https://www.fda.gov/drugs/drug-interactionslabeling/drug-development-and-drug-interactions-table-substratesinhibitors-and-inducers.

46. Campbell JR, Al-Jahdali H, Bah B, Belo M, Cook VJ, Long R, et al. Safety and efficacy of rifampin or isoniazid among people with Mycobacterium tuberculosis infection and living with human immunodeficiency virus or other health conditions: post hoc analysis of 2 randomized trials. Clin Infect Dis 2021;73:e3545-54.

47. Cruz AT, Ahmed A, Mandalakas AM, Starke JR. Treatment of latent tuberculosis infection in children. J Pediatric Infect Dis Soc 2013;2:24858.

48. Powell DA, Perkins L, Wang SH, Hunt G, Ryan-Wenger N. Completion of therapy for latent tuberculosis in children of different nationalities. Pediatr Infect Dis J 2008;27:272-4.

49. Cruz AT, Starke JR. Increasing adherence for latent tuberculosis infection therapy with health department-administered therapy. Pediatr Infect Dis J 2012;31:193-5.

50. Taylor EM, Painter J, Posey DL, Zhou W, Shetty S. Latent tuberculosis infection among immigrant and refugee children arriving in the United States: 2010. J Immigr Minor Health 2016;18:966-70.

51. Goswami ND, Gadkowski LB, Piedrahita C, Bissette D, Ahearn MA, Blain ML, et al. Predictors of latent tuberculosis treatment initiation and completion at a U.S. public health clinic: a prospective cohort study. BMC Public Health 2012;12:468.

52. Hirsch-Moverman Y, Shrestha-Kuwahara R, Bethel J, Blumberg HM, Venkatappa TK, Horsburgh CR, et al. Latent tuberculous infection in the United States and Canada: who completes treatment and why? Int J Tuberc Lung Dis 2015;19:31-8.

53. Hwang WJ, Lee GU, Kim SH, Cho EY. Childhood tuberculosis contact investigation and treatment of latent tuberculosis infection: a single center study, 2014-2017. Pediatr Infect Vaccine 2019;26:32-41.

54. Diallo T, Adjobimey M, Ruslami R, Trajman A, Sow O, Obeng Baah J, et al. Safety and side effects of rifampin versus isoniazid in children. $\mathrm{N}$ Engl J Med 2018;379:454-63.

55. Cruz AT, Starke JR. Safety and completion of a 4-month course of rifampicin for latent tuberculous infection in children. Int J Tuberc Lung Dis 2014;18:1057-61.

56. Cruz AT, Starke JR. Completion rate and safety of tuberculosis infection treatment with shorter regimens. Pediatrics 2018;141:e20172838.

57. Lardizabal A, Passannante M, Kojakali F, Hayden C, Reichman LB. Enhancement of treatment completion for latent tuberculosis infection with 4 months of rifampin. Chest 2006;130:1712-7.

58. Page KR, Sifakis F, Montes de Oca R, Cronin WA, Doherty MC, Federline $\mathrm{L}$, et al. Improved adherence and less toxicity with rifampin vs isoniazid for treatment of latent tuberculosis: a retrospective study. Arch Intern Med 2006;166:1863-70.

59. Ronald LA, FitzGerald JM, Bartlett-Esquilant G, Schwartzman K, Benedetti A, Boivin JF, et al. Treatment with isoniazid or rifampin for latent tuberculosis infection: population-based study of hepatotoxicity, completion and costs. Eur Respir J 2020;55:1902048.

60. Gaensbauer J, Aiona K, Haas M, Reves R, Young J, Belknap R. Better completion of pediatric latent tuberculosis treatment using 4 months of rifampin in a US-based tuberculosis clinic. Pediatr Infect Dis J 2018;37: 224-8.

61. Jenkins D, Davidson FF. Isoniazid chemoprophylaxis of tuberculosis. Calif Med 1972;116:1-5.

62. Mount FW, Ferebee SH. Preventive effects of isoniazid in the treatment of primary tuberculosis in children. N Engl J Med 1961;265:713-21. 
63. Comstock GW, Hammes LM, Pio A. Isoniazid prophylaxis in Alaskan Boarding schools. A comparison of two doses. Am Rev Respir Dis 1969; 100:773-9.

64. Menzies D, Adjobimey M, Ruslami R, Trajman A, Sow O, Kim H, et al. Four months of rifampin or nine months of isoniazid for latent tuberculosis in adults. N Engl J Med 2018;379:440-53.

65. Zenner D, Beer N, Harris RJ, Lipman MC, Stagg HR, van der Werf MJ. Treatment of latent tuberculosis infection: an updated network metaanalysis. Ann Intern Med 2017; 167:248-55.

66. Bastos ML, Campbell JR, Oxlade O, Adjobimey M, Trajman A, Ruslami $\mathrm{R}$, et al. Health system costs of treating latent tuberculosis infection with four months of rifampin versus nine months of isoniazid in different settings. Ann Intern Med 2020;173:169-78.

67. den Boon S, Matteelli A, Getahun H. Rifampicin resistance after treatment for latent tuberculous infection: a systematic review and metaanalysis. Int J Tuberc Lung Dis 2016;20:1065-71.

68. U.S. Food and Drug Administation. FDA Updates and press announcements on nitrosamines in rifampin and rifapentine [Internet]. Silver Spring (MD): Food and Drug Administation; 2020 [cited 2021 Mar 30]. Available from: https://www.fda.gov/drugs/drug-safety-and-availability/ fda-updates-and-press-announcements-nitrosamines-rifampin-andrifapentine.

69. Adams LV. Latent tuberculosis infection in children [Internet]. Alphen aan den Rijn: Wolters Kluwer; 2021 [cited 2021 Mar 23]. Available from: https://www.uptodate.com/contents/latent-tuberculosis-infectionin-children.

70. Ministry of Food and Drug Safety of Republic of Korea. Announcement of results of safety investigation of rifampicin-containing drugs [Internet]. Cheongju (Korea): Ministry of Food and Drug Safety; 2021 [cited 2021 Jul 30]. Available from: https://impfood.mfds.go.kr/CFBBB02F02/getCn tntsDetail?cntntsSn=358519.

How to cite this article: Oh CE, Menzies D. Four months of rifampicin monotherapy for latent tuberculosis infection in children. Clin Exp Pediatr 2022;65:214-21. https:/doi.org/ 10.3345/cep.2021.01186 